\title{
Estimation of Fitness Values for Virulence Genes in Collections of Rice Blast Fungus from Niigata Prefecture
}

\author{
Shigehisa KIYOSAWA*, Yuichi FuJIMAKI ${ }^{* *}$ and Masataka IWANO***
}

\begin{abstract}
Data on host-pathogen relationship of rice (Oryza sativa) and blast (Pyricularia oryzae) obtained in Niigata Prefecture, Japan were analyzed by application of a simulation model for following the change of pathogen genotype frequencies. The proportion of growing areas of rice varieties with various genotypes for blast resistance were obtained from statistics data and frequencies of blast-fungus genotypes for virulence were calculated from the data from 1976 to 1986 in six areas in Niigata Prefecture. The lowering of fitness values for each of avirulence genes, $A v \cdot a, A v \cdot i, A v \cdot k$ and $A v \cdot z$, accompanying the mutation to virulence was estimated by simulating the change in the frequencies of each genotype of blast fungus on the frequencies of genotypes of rice plant. Lower fitness values of virulence genes, $A v \cdot a^{+}$and $A v-i^{+}$, were obtained in all areas in Niigata Prefecture. This explains the recent predominance of a pathogen genotype, $A v-a A v \cdot i A v-k A v \cdot z$ (main race $001)$ in Niigata Prefecture, though predominance of the genotype, $A v-a^{+} A v-i A v-k A v-z$ (race number 003) was previously obtained in the Kanto District with similar gene frequencies for host resistance to Niigata Prefecture. Reverse tendencies between two genes were observed: fitness values obtained were slightly higher for the $A v \cdot a^{+}$gene and significantly lower for $A v-i^{+}$gene in mountainous areas in comparison with plain areas.
\end{abstract}

(Received November 9, 1992)

\begin{abstract}
Key words: stabilizing selection, fitness, rice blast, Oryza sativa, Pyricularia oryzae, population genetics.
\end{abstract}

\section{INTRODUCTION}

The gene and genotype frequencies for virulence of pathogens are determined mainly by directional and stabilizing selections ${ }^{20,21}$. The former causes an increase in virulence gene frequency under the existence of a resistance gene by selective reproduction of a virulence gene on a resistant variety. The latter (selection against virulence genes) inhibits the increase of the virulence gene frequency by lowering fitness of avirulence gene (accordingly, reproductive ability of the pathogen) accompanying the mutation towards virulence, even under the existence of the resistance gene. Accordingly, this affects the durability of a variety with true (vertical) resistance. The stabilizing selection is, therefore, very important to determine the strategies of disease control of crop plants by using resistance genes.

There are some studies on stabilizing selection: most of them have been carried out by comparing the reproduction rates of two fungus strains with and without a virulence gene in a greenhouse, and about half of them support the existence of the selection ${ }^{8)}$. However, conditions in a greenhouse are different from conditions in the field ${ }^{1,8}$. It is debatable whether the results obtained in the greenhouse

* Tsukuba International Agricultural Training Centre, Koyadai, Tsukuba, Ibaraki 305, Japan 筑波国際莀業研 修センター

** Division of Environment, Niigata Agricultural Experiment Station, Nagakura, Nagaoka, Niigata 940, Japan 新潟県農業試験場

*** Kyushu National Agricultural Experiment Station, Suya, Nishigoshi, Kikuchi, Kumamoto 861-11, Japan 九州農業試験場 
can be applied to agricultural practice. Therefore, the survey in the field concerning this problem becomes very important. In order to know the behavior of the pathogen population in the field, examination of the distribution of pathogenic races (genotypes) and development of a method for analysis are essential ; however, $\emptyset$ stergår ${ }^{199}$ mentioned that if asexual reproduction is predominant, the validity of estimating the fitness of certain genes, when the unit of selection is the genotypes, is questionable.

In the farmer's field, it is known that virulent races decrease after ceasing or reduction of the cultivation of a resistant variety ${ }^{3.13 .16,22)}$. There are, however, no reports on the stabilizing selection which was measured quantitatively, except some including those of Grant and Archer ${ }^{2}$, who studied the problem under conditions of presence or absence of a resistance gene.

Kiyosawa" attempted to measure the degree of stabilizing selection, from the field survey of the race frequencies of blast fungus and of frequencies of host genotypes from 1976 to 1980 in Japan. He made a computer program based on a model made by Kiyosawa and Yabuki1 ${ }^{16}$ to simulate the change in race frequencies between two given years depending upon observed frequencies of host genotypes in the two years in each prefecture in Japan. Using this program, the change in pathogen genotype frequencies between 1976 and 1980 was simulated. Starting from pathogen genotype frequencies in 1976 and giving various fitness values to virulence gene and reproductive ability $(r)$ in Table 2 is calculated by multiplication of fitness values to each genotype, frequencies of pathogen genotypes in 1980 were calculated. These frequencies were compared with the observed pathogen genotype frequencies in 1980 . Then, a fitness value, which gave expected frequencies that best agreed with the observed ones in 1980 , was selected for each virulence gene. This method is essentially the same as that used by Grant and Archer ${ }^{2)}$ except for a few points : use of $f$ (fitness value) for (1-s) in Grant and Archer ${ }^{2)}$, extension from one gene-pair system to four gene-pair system and neglect of mutation from virulence to avirulence.

Among the fitness values estimated for each region, regional differences were found for $A v \cdot a^{+}$. For example, five prefectures in the Tohoku District showed the values between 0.9 and 1 , five prefectures in the Kanto District showed 1 or 1.01, and four prefectures in the Hokuriku Region of the Chubu District showed low values, 0.7 to 0.94 . Unfortunately, because the sample size in each prefecture is not always sufficient, the reliability of the results is more or less questionable.

Kiyosawa's analysis ${ }^{9}$ on stabilizing selection from field survey is the first to estimate stabilizing selection that occurs naturally in the field containing a plural number of resistance genes. Since this kind of work in the field is very laborious and time-consuming, data from which the degree of stabilizing selection can be quantitatively estimated are very few. General or reliable conclusions can be obtained only after accumulation and analyses of data by many researchers and in many regions.

Fortunately in Niigata Prefecture, race frequencies of the blast fungus in the prefecture have been examined in every year for a relatively long time (eleven years), and $94.4 \%$ of rice growing areas are occupied by varieties of which genotypes for blast resistance are known. Since isolates of the fungus were collected at locations in a relatively high density every year, more reliable conclusion could be expected. In the present study, the data on the frequencies of the genes and genotypes for the virulence of rice blast fungus in Niigata Prefecture were analyzed especially in respect of stabilizing selection. Furthermore, the reliability of the estimates of fitness values of virulence genes was considered to be relatively high, because a significant difference was found among sub-prefectures in Niigata Prefecture.

\section{MATERIALS AND METHODS}

Niigata Prefecture consists of six areas, i.e. Joetsu, Chuetsu, Uonuma, Niigata, Kaetsu and Sado. In Fig. 1 in the previous paper ${ }^{14}$ the places where fungus isolates were collected and the method for testing of pathogenicity were shown. The proportions of growing areas of varieties cultivated in Niigata Prefecture were taken from "Statistics of Growing Areas of Rice Varieties in Niigata Prefecture" from 1976 to 1986 (Niigata Prefecture, unpublished data). The genotypes of most varieties for blast resistance have been known ${ }^{4,9-12,15)}$, but not those of two varieties, Hanahikari and Nakadamochi. Therefore, these two varieties were tested using the seven differential fungus strains ${ }^{23}$, and were determined to be " $P i-a$ 


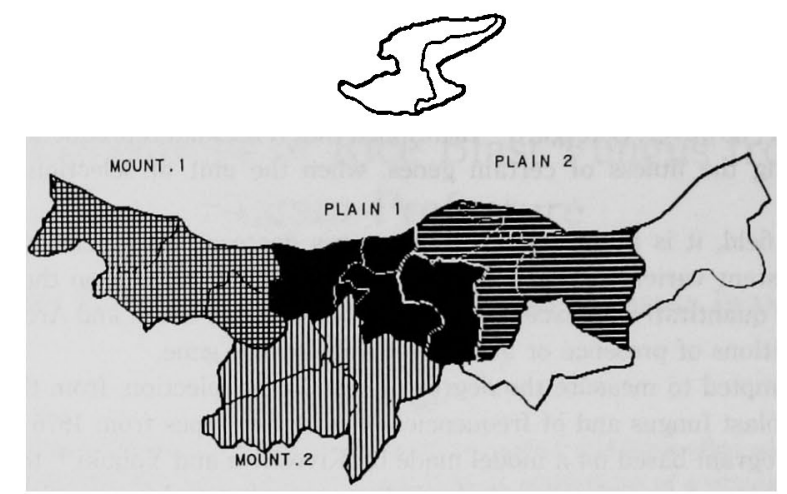

Fig. 1. Mountainous and plain areas sub-divided in Niigata Prefecture.

Table 1. Host and pathogen genotypes and corresponding pathogen races

\begin{tabular}{cccc}
\hline Code number & Host genotype & Pathogen genotype & Race \\
\hline 1 & $A I K Z$ & $a i k z$ & 001,101 \\
2 & $A I K+$ & $a i k+$ & 041 \\
3 & $A I+Z$ & $a i+z$ & 031 \\
4 & $A+K Z$ & $a+k z$ & 005 \\
5 & $+I K Z$ & $+i k z$ & 003 \\
6 & $A I++$ & $a i++$ & 045 \\
7 & $A+K+$ & $a+k+$ & 043 \\
8 & $+I K+$ & $+i k+$ & 035 \\
9 & $A++Z$ & $a++z$ & 013,033 \\
10 & $+I+Z$ & $+i+z$ & 007 \\
11 & $++K Z$ & $++k z$ & 047 \\
12 & $A+++$ & $a+++$ & 017,037 \\
13 & $+I++$ & $+i++$ & $++k+$ \\
14 & $++K+$ & $+++z$ & ++++ \\
\hline
\end{tabular}

$A+K+$ means $P_{i-a} P_{i-i^{+}} P_{i-k} P_{i-z^{+}}$genotype.

$a+k+$ means $A v \cdot a A v-i^{+} A v-k A v-z^{+}$genotype.

$P i-i$ " and "+", respectively. By this test of resistance, the proportion of rice growing area occupied by rice variety with known genotype increased from $94.4 \%$ to $96.1 \%$. In Niigata Prefecture, six resistance genes, $P i-a, P i-i, P i-k, P i-k^{\mathrm{m}}, P i-t a^{2}$ and $P i-z$, were used in farmer's fields during 1976 to 1986 . Among them, $P i-t a^{2}$ was used only in three years at a low percentage, $0.3 \%$ on average. Only 3 of 1308 isolates collected during the eleven years in Niigata Prefecture were virulent to $P i-k$ and avirulent to $P i-k^{\mathrm{m}}$ (two resistance genes are allelic), and isolates virulent to $P i-k^{\mathrm{m}}$ and avirulent to $P i-k$ have not been found similarly to the past data in $\operatorname{Japan}^{6}{ }^{6}$. Therefore, in the present simulation experiment, for simplification, $P i-k$ and $P i-k^{m}$ were represented by $P i-k$. Therefore, frequencies of 16 genotypes (Table 1) consisting of four gene-pairs for resistance and virulence, $P i-a: A v-a^{+}, P i-i: A v-i^{+}, P i-k: A v-k^{+}$and $P i-z: A v-z^{+}$, were calculated. The code numbers of host and pathogen genotypes are shown in Table 1.

Estimation of fitness of each virulence gene was conducted extending the two gene-pair model of Kiyosawa and Yabuki ${ }^{16)}$ to four gene-pair system. The detailed method has been shown in Kiyosawa".

Estimation of fitness values between two successive years, for example 1976 and 1977, was conducted as follows. Simulation was started from the pathogen genotype frequencies in 1976. If the frequency of a virulence gene was 0 at the starting point, 0.005 was given to genotypes possessing the virulence gene in consideration of mutation frequency to virulence and possible loss of virulent genotypes due to 
small size of samples. In blast fungus, frequencies of virulent mutants on cultural medium are found to be 0 to $1.5 \times 10^{-1}$, although the frequencies vary with avirulence genes ${ }^{5}$. The number of vegetative generations of blast fungus in Niigata Prefecture was assumed to be seven in a year based on the length of infection cycle and infectious period in a year in Niigata Prefecture. Expected frequencies of pathogen genotypes in 1977 were obtained by simulating the change in pathogen genotype frequencies from spring to autumn of 1977 by giving a priori various fitness values under the conditions of the frequencies of host genotypes in 1977.

Such expected pathogen frequencies were obtained by giving 1 to avirulence genes $(a, b, c$ and $d$ in Table 2) and different fitness values $\left(f_{1}, f_{2}, f_{3}\right.$ and $\left.f_{4}\right)$ to virulence genes $\left(\mathrm{a}^{+}, \mathrm{b}^{+}, \mathrm{c}^{+}\right.$and $\mathrm{d}^{+}$in Table 2$)$ at 0.01 intervals, respectively, in a simulation calculation. Accordingly, reproductive ability $\left(r_{1}\right)$ of the pathogen genotype, abcd, was 1 , and reproductive ability of genotypes, $a b c d^{+}, a b c{ }^{+} d, a b^{+} c d$ and $a^{+} b c d$ were $r_{4}\left(1 \times 1 \times 1 \times f_{4}\right), r_{3}, r_{2}$, and $\mathrm{r}_{1}$. Furthermore, for reproductive ability $\left(r_{16}\right)$ of the genotype, $\mathrm{a}^{+} \mathrm{b}^{+} \mathrm{c}^{+}$ $\mathrm{d}^{+}$, in Table $2, f_{1} \times f_{2} \times f_{3} \times f_{4}$ was given. Calculations were repeated seven times by $p^{\prime}$ obtained by calculation with Equations (1) and (2) is given to $p$ in the next generation as follows. The seven times are the putative number of infection cycles in asexual generations in a year in Niigata Prefecture.

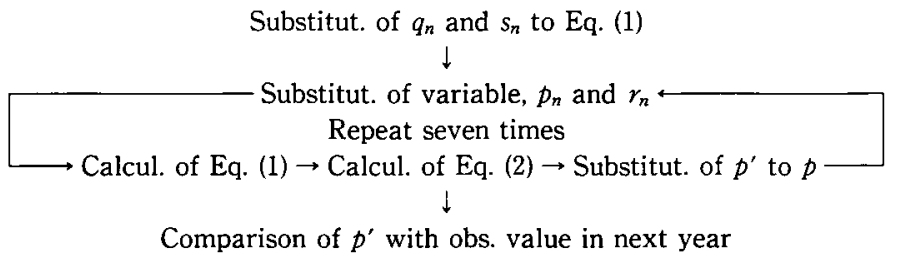

The fitness values $\left(f_{n}, n=1,2,3,4\right)$ which gave the best agreement between the expected and the observed frequencies of pathogen were taken as fitness values of the virulence genes concerned. At first we attempted to select fitness values in order to give the lowest chi square values. As a result, it was thought that the chi square test was not suitable for choice of fitness values for the following reason. Chi square values are affected mainly by a difference between calculated and observed (collected) numbers of minor genotypes.

Therefore, fitness values were taken when the expected frequencies of major genotypes best approached to the observed pathogen frequencies: that is, when $\Sigma$ expected frequency-observed frequencyl is at minimum. These estimations were performed every year in each area and in the whole of Niigata Prefecture.

When an observed change of pathogen genotype frequencies fit with that obtained by giving product of fitness values of virulence genes included to all pathogen genotypes, we considered that there is general interaction of the two virulence genes, and when it did not fit, the existence of specific interaction between the two genes was presumed.

In Table 2 , the frequency $\left(p_{1}{ }^{\prime}\right)$ in the next generation of the genotype, abcd, is calculated by $p_{1} \gamma_{1} Q_{16} /$ $T$. The $p_{1}{ }^{\prime}$ thus obtained was used as $p_{1}$ for calculation of the $p_{1}{ }^{\prime}$ in the next generation. The same principles were applied to all 16 genotypes.

\section{RESULTS}

\section{Estimation of fitness values for virulence gene}

For a simulation attempted in the study, data on the frequencies of pathogen and host genotypes in two sequential years are necessary. In some areas and years, data sufficient to calculate the frequencies were not available, because the number of isolates collected was too small due to lack of infections. In most years Sado area was excluded from calculation and in some years, other areas. Furthermore, in all areas, special fitness values of $A v \cdot k^{+}$or $A v \cdot z^{+}$could not be determined for some years, because the range of fitness values which showed sufficiently low total of the difference between expected and observed frequencies was too wide for these two genes. When expected frequencies of pathogen 


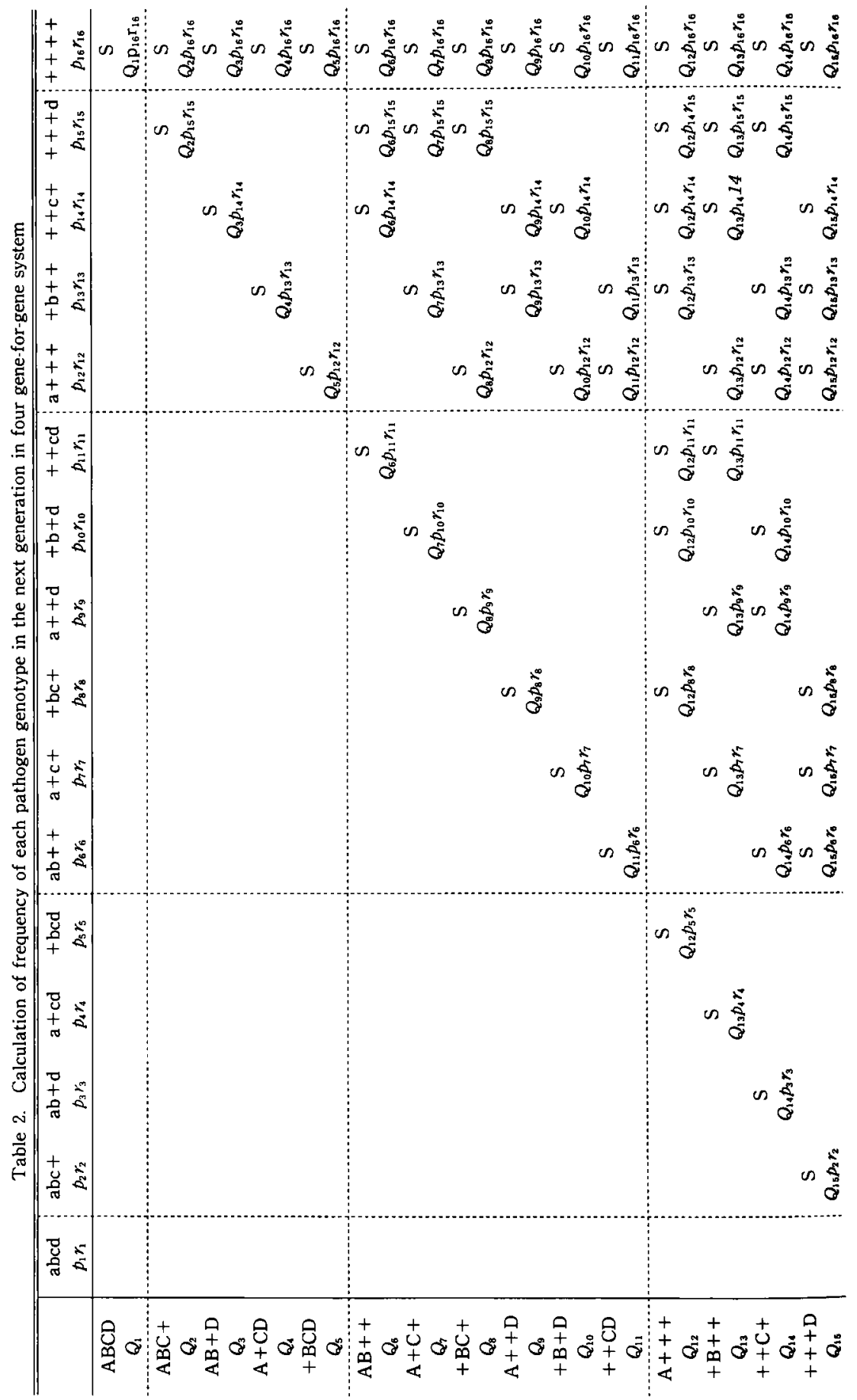




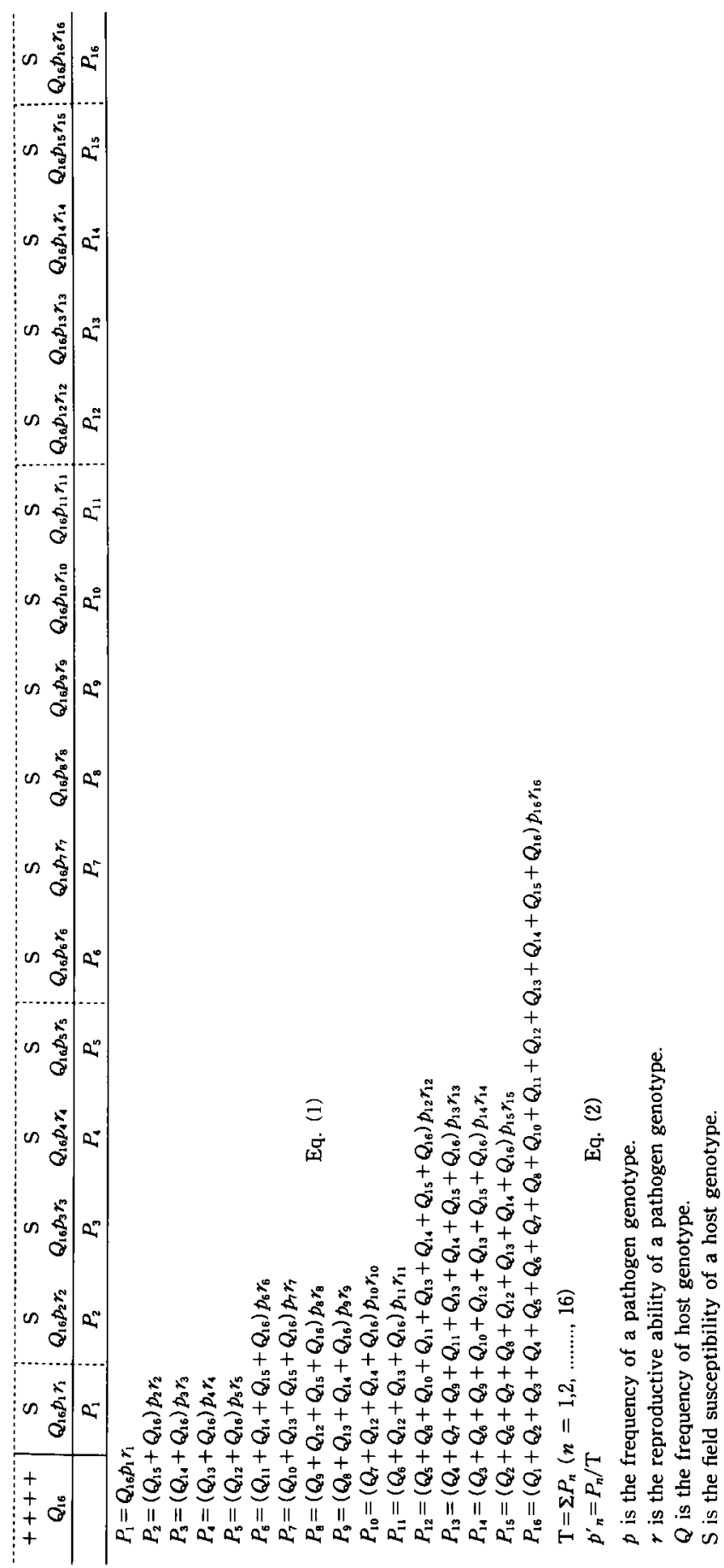




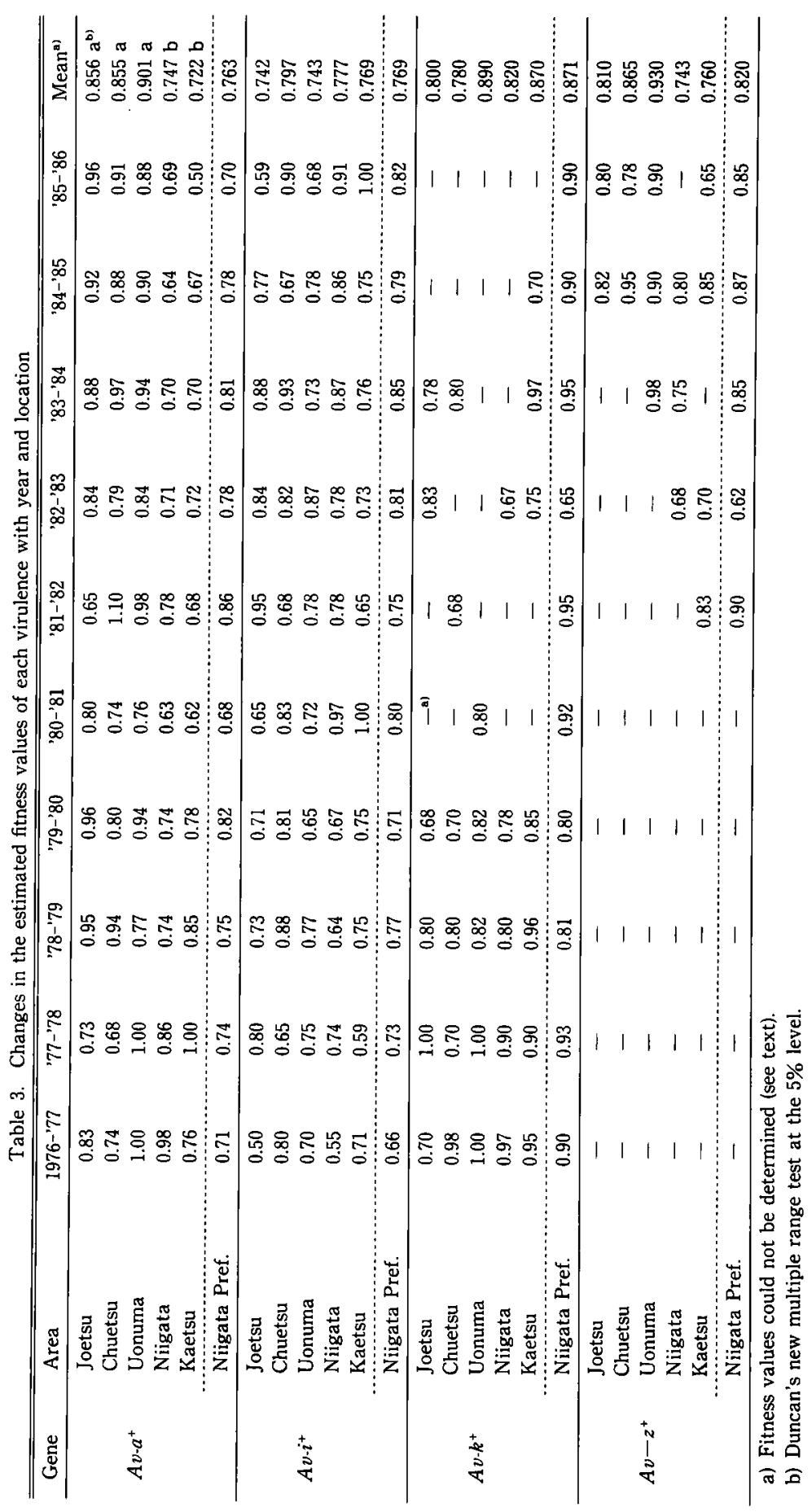


genotypes were judged to agree with the observed ones, the distributions of the number of virulence genes in an isolate always showed a good agreement with expected (obtained from simulaion) distributions. The fitness values were calculated in the whole of Niigata Prefecture and five areas except Sado as shown in Table 3. Almost all of the values obtained were less than 1 for all virulence genes, areas and years calculated.

Except for 1980-1981 which showed especially low fitness values in all areas, a relatively small yearly variation was observed for $A v-a^{+}$. This indicates that this value has a relatively high reliability. In the whole prefecture, mean fitness values of $A v \cdot a^{+}, A v \cdot i^{+}, A v-k^{+}$and $A v-z^{+}$were $0.76,0.77,0.87$ and 0.82 , respectively.

The geographical difference of fitness values of $A v-a^{+}$and $A v \cdot i^{+}$was tested by analysis of variance. Upper-half data in Table 3 were separately tested by the analysis of variance in two way classification of five areas and ten years in relation to two virulence genes $\left(A v-a^{+}\right.$and $\left.A v-i^{+}\right)$. Tests showed significant difference between areas in $A v \cdot a^{+}$at the $5 \%$ level but not in $A v-i^{+}$.

\section{The infuence of environmental conditions on fitness values of virulence genes}

Joetsu and Uonuma areas are mountainous, and Sado is relatively flat. Niigata and Kaetsu include mountainous and flat area. Chuetsu is flat. In order to examine the influence of such difference in geographical circumstances, Niigata Prefecture was divided into four areas: two mountainous areas and two plain areas (Fig. 1), excluding Sado, and mountainous parts in both Niigata and Joetsu, where the numbers of isolates collected were very few.

Fitness values of $A v-a^{+}$and $A v-i^{+}$in each of the four areas are shown in Table 4. Data of fitness values were analyzed in the three way classification of two areas $\times$ nine years $\times$ two genes $\left(A v \cdot a^{+}\right.$and $\left.A v-i^{+}\right)$. The interaction between genes $\times$areas was significant at the $1 \%$ level, indicating that the influence of areas on fitness values is different between mountainous and plain areas. Therefore, analysis was separately performed in relation to virulence genes, $A v \cdot a^{+}$and $A v-i^{+}$. The mean fitness value of $A v \cdot a^{+}$in the plain areas was lower than those of the mountainous areas, although not significant at the 5\% level, while significant differences were observed between the two areas for $A v \cdot i^{+}$.

\section{DISCUSSION}

1. Estimation of fitness values for virulence genes: As described above, fitness values given for each of the four virulence genes, $A v-a^{+}, A v-i^{+}, A v-k^{+}$and $A v-z^{+}$, were less than 1 . Thus it was suggested that stabilizing selection on each of the four virulence genes functioned in Niigata Prefecture. The fitness value of $A v-a^{+}$was specifically lower than those in prefectures in the Kanto or Tohoku District obtained before (Kiyosawa'). In fact, the frequency of pathogen genotype, $A v \cdot a A v-i A v-k A v-z$, (abbreviated as aikz, hereafter) (mainly race 001, see Table 1) increased during the eleven years and became dominant in Niigata Prefecture (pathogen genotype code number 1 in Fig. 2 in the previous paper $\left.{ }^{14}\right)$. In prefectures in the Kanto and Tohoku District, aikz was, however, very low and $+i k z$ genotype (race 003, pathogen genotype code number 5 in Fig. 2 in the previous paper ${ }^{14)}$ ) dominated in 1976 and 1980. Therefore, it was thought that the low fitness of $A v-a^{+}$led to the increase of frequency of aikz pathogen genotype in Niigata Prefecture.

Moreover, as shown in Fig. 2 in the previous paper ${ }^{14)}$, frequencies of virulence genes $A v \cdot a^{+}, A v-i^{+}$ and $A v-k^{+}$decreased during the eleven years in the whole prefecture. It was thought that the effect of stabilizing selection was perhaps stronger than that of directional selection on the three virulence genes $\left(A v-a^{+}, A v-i^{+}\right.$and $\left.A v-k^{+}\right)$, leading to the decrease of the frequencies in Niigata Prefecture.

As for the geographical differences of fitness values for $A v-a^{+}$and $A v-i^{+}$, the values of $A v-a^{+}$in mountainous areas were considerably higher than that in plain areas, but significantly higher fitness values were obtained in plain areas as compared with mountainous areas for $A v-i^{+}$. Accumulation of more data of this type is required to get a definite conclusion.

As mentioned above, differences of fitness values were recognized between districts in Japan and between areas in a prefecture. Difference of fitness had been found between glasshouse experiment and field-data by Grant and Archer ${ }^{2}$, although they expressed fitness by $(1-s)$. The higher fitness under 
Table 4. Fitness values in

\begin{tabular}{clcccc}
\hline \hline Gene & Area & $1976-77$ & $77-78$ & $78-' 79$ & $79-{ }^{\prime} 80$ \\
\hline \multirow{3}{*}{$A v \cdot a^{+}$} & Mount. 1 (Joetsu) & 0.83 & 0.73 & 0.95 & 0.96 \\
& Mount. 2 (Uonuma) & 1.00 & 1.00 & 0.77 & 0.94 \\
& Plain 1 (Chuetsu) & 0.74 & 0.68 & 0.94 & 0.80 \\
& Plain 2 & 0.96 & 0.95 & 0.60 & 0.68 \\
\hline \multirow{3}{*}{$A v-i^{+}$} & Mount. 1 (Joetsu) & 0.50 & 0.80 & 0.73 & 0.71 \\
& Mount. 2 (Uonuma) & 0.70 & 0.75 & 0.77 & 0.65 \\
& Plain 1 (Chuetsu) & 0.80 & 0.65 & 0.88 & 0.81 \\
& Plain 2 & 0.66 & 0.70 & 0.70 & 0.66 \\
\hline
\end{tabular}

a, b) See Table 3 .

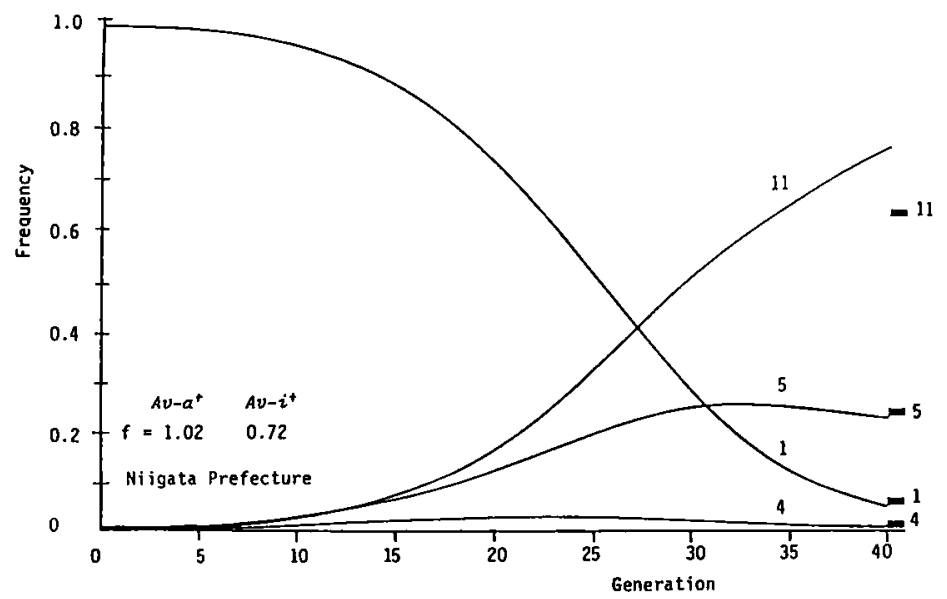

Fig. 2. Simulated frequency curves of pathogen genotypes which showed best fit to the observed frequencies in 35th generation; starting from observed frequencies in 1972 (left in the figure) till 1976. Numerals and bars described on the righthand side of each curve and the position of genotype frequencies observed in 1976, respectively. The $\mathrm{f}$ is fitness value for $A v-a^{+}$and $A v-i^{+}$. The same mutation frequencies $(0.005)$ were given on the four avirulence loci, and the change of frequencies was calculated based on the mean proportions of growing areas of rice genotypes between 1972 and 1976 . A set of curves best agreed with the observed frequencies at 35 th generation in this figure.

glasshouse conditions was attributed to the higher pathogen population densities in glasshouse experiments (Leonard ${ }^{17)}$, personal communication with Grant and Archer). Previously higher fitness values were obtained in less infected districts in Japan ${ }^{9}$. In the present paper fitness values were higher in more infected areas and less infected areas for $A v \cdot a^{+}$and $A v-i^{+}$, respectively, in Niigata Prefecture. In this sense, our results do not always support Leonard's suggestion mentioned above. More studies are necessary to determine the cause of decrease of fitness values.

2. Cause of non-random association between $A v-a^{+}$and $A v \cdot i^{+}$: A specific interaction of the genes $A v \cdot a^{+}$and $A v-i^{+}$occurring by the relations, $r_{6} \neq f_{3} \times f_{4}$ was considered as a cause of non-random association. It was examined by Kiyosawa's simulation model whether the non-random association can be explained only by the stabilizing selection and directional selection or not. Many simulations were run to get the frequencies of pathogen genotypes in 1976 by giving various fitness values at 0.01 intervals separately to four virulence genes, under the conditions, where the mutation frequencies $(0.005)$ were given to four avirulence loci and $r_{6}$ equals $f_{3} \times f_{4}$, on the mean proportion of growing areas of the rice genotypes between 1972 and 1976.

Some sets of simulated curves of frequencies passing through near the observed frequencies in 1976 


\begin{tabular}{|c|c|c|c|c|c|c|}
\hline '80-'81 & '81-'82 & '82-'83 & '83-'84 & '84-'85 & '85-'86 & Mean $^{a)}$ \\
\hline 0.80 & 0.65 & 0.84 & 0.88 & 0.92 & 1.00 & 0.886 \\
\hline 0.76 & 0.98 & 0.84 & 0.94 & 0.90 & 0.88 & \\
\hline 0.74 & 1.10 & 0.79 & 0.97 & 0.88 & 0.91 & 0.764 \\
\hline 0.55 & 0.67 & 0.68 & 0.66 & 0.62 & 0.61 & \\
\hline 0.65 & 0.95 & 0.84 & 0.88 & 0.77 & 0.59 & $0.728 \mathrm{a}^{\mathrm{b})}$ \\
\hline 0.72 & 0.78 & 0.87 & 0.73 & 0.78 & 0.68 & \\
\hline 0.83 & 0.68 & 0.82 & 0.93 & 0.67 & 0.90 & $0.808 \mathrm{~b}$ \\
\hline 1.05 & 0.80 & 0.83 & 0.82 & 0.85 & 0.98 & \\
\hline
\end{tabular}

were thus obtained, although the duration of the passage near the observed frequencies in 1976 was short (Fig. 2). In all of them, the fitness values obtained to explain the observed frequency curves greatly differed from those obtained in Table 3 . When fitness values obtained in the above analyses were given, curves approaching the observed frequencies could not be obtained. Accordingly, there is a possibility that specific reproductive ability (specific interaction) is produced in the combination of $A v-a$ and $A v-i$ loci. However, the possibility that the observed non-random association between $A v \cdot a^{+}$and $A v-i^{+}{ }^{7}$ can be explained only by directional selection and stabilizing selection under general interaction between the two avirulence loci cannot be completely eliminated, as it is very difficult to simulate all possible conditions. As a final conclusion could not be drawn from the methods employed in the present paper, it is necessary to devise other methods to detect the presence or absence of specific interaction of two avirulence loci.

3. Change of race (genotype) frequencies in Niigata Prefecture: In Niigata Prefecture, the fungal genotype $A v-a^{+} A v-i^{+} A v-k A v-z$ (number 11 in Fig. 2 in the previous paper ${ }^{14)}$ ) sharply decreased with increase of the genotype $A v \cdot a A v-i A v-k A v \cdot z$ (number 1). This remarkable decrease is considered to be due to low fitness of $A v \cdot a^{+}$and $A v \cdot i^{+}$genes and probably due to the gradual increase from $34 \%$ in 1966 to $82.4 \%$ in 1986 of growing area of Koshihikari which is a variety having low field resistance. If this is the case, we cannot explain a high frequency of $A v-a^{+} A v-i^{+} A v-k A v-z$ in 1976. It is partly due to an accumulative effect of cultivation of Yamahibiki having Pi-a and Pi-i from 1961 to 1968, as Matsumoto et $a{ }^{1{ }^{18)}}$ demonstrated that the accumulative effect of cultivation of resistant varieties is very large. However, Kiyosawa' ${ }^{9}$ has failed to explain high frequencies of complex races of blast fungus when varieties with specific resistance were not cultivated. Change of race frequencies which cannot be simply explained solely by only stabilizing selection and/or directional selection seems present.

We would like to thank Dr. T. Hino, former Director of the National Institute of Agrobiological Resources, for his valuable suggestions in writing this manuscript.

\section{Literature cited}

1. Antonovics, J. and Alexander, H.M. (1989). The concept of fitness in plant-fungal pathogen systems. In: Plant Disease Epidemiology II (Leonard, K.J. and Fry, W.E., eds.), pp. 185-214. McGraw-Hill Publishing Company, New York, Tokyo.

2. Grant, M.W. and Archer, S.A. (1983). Calculation of selection coefficients against unnecessary genes for virulence from field data. Phytopathology $73: 547-551$.

3. Iwano, M. and Yamada, M. (1983). Studies on the distribution of races of rice blast fungus, Piricularia oryzae Cavara, in the paddy fields and the factors affecting the prevalence of races. Bull. Hokuriku Agr. Expt. Sta. 25 : 1-64 (in Japanese).

4. Kiyosawa, S. (1974). Studies on genetics and breeding of blast resistance in rice. Misc. Publ. Natl. Inst. Agr. Sci. D1 : 1-58 (in Japanese).

5. Kiyosawa, S. (1976). Pathogenic variations of Pyricularia oryzae and their use in genetic and breeding studies. SABRAO J. 8: 53-67.

6. Kiyosawa, S. (1977). Knowledge obtained by pathogenicity tests of Pyricularia oryzae. Agr. Hort. $52: 327-$ 328 (in Japanese). 
7. Kiyosawa, S. (1980). On the virulence analysis of pathogen race frequencies. Ann. Phytopath. Soc. Japan $46: 582-593$.

8. Kiyosawa, S. (1981). Breeding for disease resistance in crop plants and its basic studies. Agr. Hort. 56 : 1563-1568 (in Japanese).

9. Kiyosawa, S. (1986). Estimation of stabilizing selection of virulence genes in the rice blast fungus population in prefectures of Japan. Bull. Natl. Inst. Agrobiol. Resour. 2: 61-91.

10. Kiyosawa, S. (1989). Breakdown of blast resistance in rice in relation to general strategies of resistance gene deployment to prolong effectiveness of disease resistance in plants. In Plant Disease Epidemiology II (Leonard, K.J. and Fry, W.E., eds.), pp. 251-283. McGraw-Hill Publishing Company, New York, Tokyo.

11. Kiyosawa, S., Aihara, J., Inoue, M. and Matsumoto, N. (1979). Classification of rice varieties based on true-resistance to blast I. Jpn. J. Breed. $29: 77-83$ (in Japanese).

12. Kiyosawa, S., Aihara, J., Inoue, M. and Matsumoto, N. (1979). Classification of rice varieties based on true-resistance to blast II. Jpn. J. Breed. $29: 166$-170 (in Japanese).

13. Kiyosawa, S., Ando, I., Ishiguro, K., Nemoto, F. and Hashimoto, A. (1991). Three examples of yearly change of frequencies of unnecessary virulence genes under field conditions where resistance genes for rice blast are not present. Bull. Fukushima Agr. Expt. Sta. 30:23-36.

14. Kiyosawa, S., Fujimaki, Y. and Iwano, M. (1993). Collections of blast fungus from resistant rice varieties and their frequencies of races and virulence genes. Ann. Phytopath. Soc. Japan 59 : 387-395.

15. Kiyosawa, S., Orimoto, Y. and Iida, S. (1984). Relationship between frequencies of resistance gene in the host and corresponding virulence gene in the pathogen in rice blast disease. Jpn. J. Breed. 34:322-334.

16. Kiyosawa, S. and Yabuki, S. (1976). Modeling on the race frequency change in a host-pathogen system with genes for resistance and avirulence. Japan. J. Breed. $26: 237-246$.

17. Leonard, K.J. (1987). The host population as a selective factor. Populations of Plant Pathogens: their Dynamics and Genetics (Wolfe, M.S. and Caten, C.E. eds.). Blackwell Scientific Publications, Oxford. pp. 163-179.

18. Matsumoto, N., Kiyosawa, S., Terasawa, M. and Inoue, M. (1979). Prediction of the virulent-race frequencies by the percent growing areas of rice varieties with blast-resistance genes. Bull. Ishikawa Agr. Expt. Sta. 10: 1-16 (in Japanese).

19. Østergård, H. (1987). Estimating relative fitness in asexually reproducing plant pathogen populations. Theor. Appl. Genet. $74: 87-94$.

20. Van der Plank, J.E. (1963). Plant Diseases : Epidemics and Control. Academic Press, New York. pp. 349.

21. Van der Plank, J.E. (1968). Disease Resistance in Plants. Academic Press, New York and London. pp. 206.

22. Watson, I.A. and Luig, N.H. (1963). The classification of Puccinia graminis var. tritici in relation to breeding resistant varieties. Proceedings of Linnean Society, New South Wales 88 : 235-258.

23. Yamasaki, Y. and Kiyosawa, S. (1966). Studies on inheritance of resistance of rice varieties to blast. I. Inheritance of resistance of Japanese varieties to several strains of the fungus. Bull. Natl. Inst. Agr. Sci. D14 : 39-69 (in Japanese).

\section{和 文 摘 要}

\section{清沢茂久・藤巻雄一・岩野正敬：新潟県におけるイネいもち病の宿主・病原菌関係の集団寈伝学的分析}

新潟県のイネいもち病関係の資料を用いて, 病原菌の遺云子型頻度の変化の実態と, 安定化選択の原因となる病原性 に変化するために起こる菌の相対適応度の低下の年次変動と地域間差異, 遭伝子間差異について検討を行った。新淿県 を 6 地区に分け，それぞれの 1976 年から 1986 年の 11 年間の品種の作付面積率から，抵抗性遗伝子 Pi-a, Pi-i, Pi-k, $P i-z$ とその罹病性の対立遗伝子からなる 16 の遗层子型の頻度を求め, また, その期間のいもち病菌のレース頻度から 上記の抵抗性遺伝子に対応する病原性に関する 16 の遗伝子型頻度を求めた。古る抵抗性遭伝子の分布する地区で病 原菌のレースの変化を追跡するための Kiyosawa のモデルを使用して，上記の 4 つの非病原性遺伝子座の非病原性通 伝子が病原性遗层子に変化した場合の, 相対適応度 (各非病原性遺层子の適応度を 1 とした時の適応度)を計算した。 その結果, 病原性遺伝子の相対適応度は $A v-a^{+}, A v \cdot i^{+}, A v-k^{+}, A v-z^{+}$のいずれの寈伝子でも1より低く（県平均てそ れぞれ $0.77,0.77 ０ .88 ， 0.85$ ), 病原性に変わることによりその菌系の適応度が低下したことを示した。特に $A v \cdot a か$ ら $A v \cdot a^{+}$に変わることによる適応度 (平均 0.77) の低下は, 1961 年から 1980 年までの全国のデータを用いて県毎に同 様な検討をした Kiyosawa の新渴県の值と近い值を示し，北陸地方における $A v \cdot a^{+}$遺层子への変化による適応度の低 下は独特のものであることを襄付けた。このことが, 北陸地方で他の地方と比べ,レース001の率が特に多い原因に なっているものと考えられる。山間值と平地との間の相対適応度を比較すると, $A v \cdot a^{+}$については山間値の適応度がわ ずかに高く, $A v-i^{+}$については山間值が有意に低かった。 